\title{
BIOKONVERSI BAHAN ORGANIK PADA PENGOLAHAN AIR LIMBAH INDUSTRI PULP DAN KERTAS MENJADI ENERGI LISTRIK MENGGUNAKAN MEMBRANE-LESS MICROBIAL FUEL CELL (ML-MFC)
}

\author{
Kristaufan Joko Pramono ${ }^{1}$, Krisna Adhitya Wardhana, Prima Besty Asthary, Saepulloh \\ Balai Besar Pulp dan Kertas \\ Jl. Raya Dayeuhkolot No. 132, Bandung \\ ${ }^{1}$ kristaufan@yahoo.com
}

Diterima : 20 Februari 2015, Revisi akhir : 24 April 2015, Disetujui terbit : 8 Mei 2015

\section{BIOCONVERSION ON WASTEWATER TREATMENT OF PULP AND PAPER MILL USING MEMBRANE-LESS MICROBIAL FUEL CELL (ML-MFC)}

\begin{abstract}
Pulp and paper industry produces large amount of wastewater that has high pollution potentials. Nowadays, development of renewable energy resources is being researched. Membrane-less Microbial Fuel Cell (ML-MFC) can be an alternative for wastewater treatment and bioenergy producers of renewable electricity. This study was subjected to evaluate the performance of ML-MFC in pulp and paper wastewater treatment and to analyze the potentials production of electricity energy. ML-MFC reactors in laboratory scale used in this experiment were made of acrylic, provided with electrodes functioning as anode and cathode which have surface area of $1.4778 \times 10^{-2} \mathrm{~m}^{2}$ and $4.926 \times 10^{-3} \mathrm{~m}^{2}$, respectively. In this experiment, wastewater from pulp and paper mill was continuously fed into the reactor with retention time of 48 hours and organic load about $0.23-0.51 \mathrm{~kg} C O D / \mathrm{m}^{3}$.day. The results showed that there was potential of electricity production from pulp and paper mill's wastewater treatment by ML-MFC. The maximum COD reduction and maximum power supply voltage that could be achieved were $38.50 \%$ and $118.8 \mathrm{mV}$, respectively. The maximum electric power obtained on the anode surface area of $1.4778 \times 10^{-2} \mathrm{~m}^{2}$ was $8.46 \mathrm{~mW} / \mathrm{m}^{2}$ when the electric current value was $101.50 \mathrm{~mA} / \mathrm{m}^{2}$ and the resistance was $500 \Omega$.
\end{abstract}

Keywords: wastewater, organic, bioconversion, electricity, membrane-less microbial fuel cell (ML-MFC)

\section{ABSTRAK}

Industri pulp dan kertas menghasilkan air limbah dalam jumlah besar yang memiliki potensi pencemaran tinggi. Saat ini, upaya pengembangan sumber energi terbarukan terus dilakukan. Membraneless Microbial Fuel Cell (ML-MFC) adalah salah satu alternatif pengolahan air limbah dan penghasil bioenergi listrik yang dapat terbarukan. Penelitian ini dilakukan untuk mengevaluasi kinerja ML-MFC dalam pengolahan air limbah pulp dan kertas proses biologi dan menganalisa potensi produksi energi listrik. Reaktor ML-MFC skala laboratorium yang digunakan dalam percobaan terbuat dari akrilik dengan rangkaian elektroda yang berfungsi sebagai anoda dengan luas permukaan $1,4778 \times 10^{-2} \mathrm{~m}^{2}$ dan katoda dengan luas permukaan $4,926 \times 10^{-3} \mathrm{~m}^{2}$. Pada percobaan ini, air limbah industri pulp dan kertas dialirkan melalui reaktor secara kontinu dengan waktu tinggal 48 jam dan beban organik $0,23-0,51 \mathrm{~kg}$ $\mathrm{COD} / \mathrm{m}^{3}$.hari. Hasil penelitian menunjukkan bahwa terdapat potensi produksi energi listrik dari proses pengolahan air limbah industri pulp dan kertas oleh ML-MFC. Reduksi maksimum nilai COD dan tegangan listrik maksimum yang dapat dicapai adalah $38,50 \%$ dan $118,8 \mathrm{mV}$. Daya listrik maksimum yang diperoleh pada luas permukaan anoda sebesar $1,4778 \times 10^{-2} \mathrm{~m}^{2}$ adalah $8,46 \mathrm{~mW} / \mathrm{m}^{2}$ pada saat nilai arus listrik $101,50 \mathrm{~mA} / \mathrm{m}^{2}$ dan beban resistansi $500 \Omega$.

Kata kunci: air limbah, organik, biokonversi, energi listrik, membrane-less microbial fuel cell (ML-MFC) 


\section{PENDAHULUAN}

Air limbah industri pulp dan kertas dihasilkan dalam jumlah besar dan memiliki potensi pencemaran tinggi. Oleh karena itu, pengolahan air limbah perlu dilakukan untuk meminimasi potensi pencemaran. Salah satu upaya yang dapat dilakukan adalah mengubah bahan organik yang terkandung dalam air limbah menjadi sumber energi listrik melalui teknologi Microbial Fuel Cell (MFC). Selain menurunkan potensi pencemaran, MFC dapat menghasilkan energi listrik yang dapat langsung digunakan.

Saat ini, MFC merupakan teknologi baru sebagai sumber energi bio-elektrokimia yang sangat menjanjikan untuk membangkitkan energi listrik. MFC merupakan teknologi yang ideal dalam pembentukan bioenergi listrik terbarukan karena sifat fleksibilitas mikroorganisme (Logan, 2009) yang dapat mengkonversi berbagai macam sumber energi dari material organik yang dapat terdegradasi, baik yang berupa senyawa sederhana seperti karbohidrat dan protein, dan juga senyawa kompleks yang terdapat dalam air limbah (Logan, 2008; Logan dan Regan, 2006; You dkk., 2007; Logan, 2004) seperti lignoselulosa. Hasil proses biodegradasi senyawa organik dikonversi hingga menjadi energi listrik berupa elektron yang dilepaskan mikroorganisme yang bergerak menuju elektroda (Huang dkk., 2009). Penggunaan MFC dapat mengubah energi yang tersimpan dalam ikatan kimiawi pada substrat organik dalam air limbah menjadi energi listrik melalui reaksi katalis yang dilakukan oleh mikroorganisme. Bakteri dapat berfungsi di dalam MFC untuk menghasilkan energi listrik pada saat bersamaan dengan berlangsungnya proses biodegradasi materi organik dalam air limbah.

Dalam pengolahan air limbah, MFC menjadi teknologi yang menarik karena proses ini mengkonversi sebagian besar energi kimia yang terdapat dalam kontaminan organik menjadi energi listrik sehingga dapat mengurangi pembentukan lumpur (Jang dkk.,2004; Kim dkk., 2004). Keunggulan dari penggunaan MFC untuk pengolahan air limbah meliputi: bersih, aman, kinerja yang tidak bising, emisi rendah, efisiensi tinggi, dan memproduksi langsung energi listrik (Ghangrekar dan Shinde, 2006a) Namun demikian, aplikasi MFC pada sistem pengolahan air limbah skala besar akan terkendala dengan penggunaan membran. Oleh karena itu, MFC tanpa membran atau ML-MFC (MembranelessMicrobial Fuel Cell) perlu dikembangkan agar memiliki peluang untuk penerapannya di industri. Hasil penelitian ini diharapkan dapat menjadi salah satu alternatif pengolahan air limbah dengan produksi listrik yang berasal dari sumber terbarukan tanpa emisi karbondioksida. Tulisan ini melaporkan evaluasi efektivitas kinerja MLMFC dan potensi produksi energi listrik yang dapat dihasilkannya dalam sistem pengolahan biologi air limbah pulp dan kertas.

\section{BAHAN DAN METODE}

Bahan yang digunakan dalam percobaan ini adalah air limbah industri pulp dan kertas terpadu sedangkan inokulum berupa lumpur bakteri yang berasal dari Instalasi Pengolahan Air Limbah (IPAL) di bagian proses lumpur aktif. Peralatan yang digunakan adalah reaktor MLMFC, multimeter, aerator, difuser dan beberapa komponen elektronik seperti LED dan resistor. Metode penelitian meliputi tahapan kegiatan sebagai berikut:

\section{Karakterisasi Air Limbah dan Perlakuan Awal Lumpur Bakteri}

Air limbah diuji terlebih dahulu untuk mengetahui karakteristik awalnya sehingga dapat diketahui beberapa parameter seperti $\mathrm{COD}_{\mathrm{T}}$, $\mathrm{BOD}_{5}$ TSS, dan $\mathrm{pH}$. Berdasarkan penelitian yang dilakukan oleh Ghangrekar dan Shinde (2006a, 2006b), lumpur bakteri yang akan digunakan dipanaskan terlebih dahulu pada suhu $100^{\circ} \mathrm{C}$ selama 15 menit untuk menghambat bakteri metanogenesis, kemudian didinginkan. Lalu lumpur tersebut sebanyak 1 liter dimasukkan ke dalam ruang anoda di dalam reaktor ML-MFC. Pada ruang katoda tidak ada penambahan bakteri.

\section{Perancangan dan Pembuatan Reaktor MFC}

Reaktor ML-MFC skala laboratorium yang digunakan dalam percobaan terbuat dari "fiber glass" transparan dengan diameter dalam 0,095 $\mathrm{m}$ dan tinggi 0,49 $\mathrm{m}$ sehingga dapat memberikan ruang untuk menampung air limbah dengan volume 3,47 L. Bahan yang dipergunakan untuk elektroda (anoda dan katoda) adalah batang karbon. Pada ruang anoda terdapat tiga rangkaian elektroda dengan luas masing-masing permukaan rangkaian elektroda adalah $4,926 \mathrm{x}$ 
$10^{-3} \mathrm{~m}^{2}$, sehingga luas permukaan total elektroda yang berfungsi sebagai anoda adalah 1,4778 $\mathrm{x} 10^{-2} \mathrm{~m}^{2}$. Sedangkan di ruang katoda terdapat satu rangkaian elektroda dengan luas permukaan $4,926 \times 10^{-3} \mathrm{~m}^{2}$.

\section{Percobaan Pengolahan Air Limbah Menggunakan ML-MFC}

Proses pengolahan air limbah menggunakan ML-MFC dapat dilihat pada Gambar 1. Air limbah (influen) dipompa dengan debit 1,2 mL/ menit untuk mencapai waktu tinggal 48 jam memasuki ruang anoda yang dikondisikan dalam suasana anaerob, kemudian memasuki ruang katoda yang dikondisikan aerob, setelah itu dialirkan keluar dari reaktor ML-MFC (efluen). Peralatan aerator digunakan pada ruang katoda berfungsi untuk mengkondisikan ruang katoda agar menjadi aerob. Elektron yang dihasilkan dari reaksi anaerob akan ditangkap oleh anoda yang kemudian akan mengalir menuju katoda melalui rangkaian listrik yang terdiri dari resistor (R). Pada resistor tersebut dilengkapi dengan alat ukur tegangan (V) dan arus listrik (A) yang berguna untuk mengetahui besaran tegangan dan arus listrik yang melaluinya.

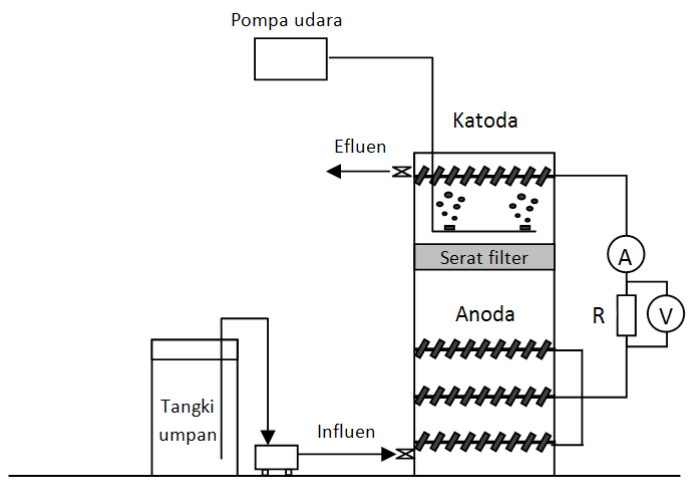

Gambar 1. Rangkaian Percobaan ML-MFC
Proses pengolahan air limbah menggunakan ML-MFC berlangsung secara kontinu dengan waktu tinggal 48 jam. Untuk mengetahui kinerja maksimum yang dapat dihasilkan oleh sistem ML-MFC, pengukuran tegangan listrik yang timbul pada anoda-katoda dilakukan dengan menggunakan multimeter yang diukur bersamaan dengan pengujian konsentrasi COD pada influen dan efluen setiap minggunya selama 63 hari. Kadar konsentrasi COD dianalisa berdasarkan Standard Methods for Examination of Water and Waste Water (APHA). Selanjutnya, dilakukan percobaan pengukuran tegangan listrik pada serangkaian variasi nilai beban resistor dalam kisaran 100-1000 $\Omega$ dengan interval $100 \Omega$ dan dalam kisaran 1000-5000 $\Omega$ dengan interval 500 $\Omega$. Nilai tegangan listrik dan arus listrik yang diperoleh dengan variasi nilai beban resistor 100 $-5000 \Omega$ digunakan untuk mengukur daya listrik maksimum yang dapat ditimbulkan oleh sistem.

\section{HASIL DAN PEMBAHASAN}

\section{Karakteristik Air Limbah Industri Pulp dan Kertas}

Karakteristik air limbah industri pulp dan kertas yang digunakan pada percobaan ini dapat dilihat pada Tabel 1. Air limbah industri pulp dan kertas yang digunakan pada percobaan ini memiliki konsentrasi $\mathrm{COD}_{\mathrm{T}}$ dan $\mathrm{BOD}_{5}$ yang melebihi ambang batas baku mutu limbah cair bagi kegiatan industri yang tercantum pada Keputusan Menteri Negara Lingkungan Hidup No. 5 Tahun 2014 Tentang Baku Mutu Air Limbah sehingga diperlukan pengolahan lebih lanjut untuk mencapai nilai baku mutu. Pada percobaan ini, kandungan organik yang tinggi yang terdapat di dalam limbah dapat dimanfaatkan menjadi energi listrik melalui proses biokonversi dengan menggunakan reaktor ML-MFC.

Tabel 1. Karakteristik Air Limbah Industri Pulp dan Kertas

\begin{tabular}{ccccc}
\hline No. & Parameter & Unit & Konsentrasi $^{*}$ & Baku Mutu (KepMenLH, 2014) \\
\hline 1. & $\mathrm{COD}_{\mathrm{T}}$ & $\mathrm{mg} / \mathrm{L}$ & $452-1012$ & $100-350$ \\
2. & $\mathrm{BOD}_{5}$ & $\mathrm{mg} / \mathrm{L}$ & $17-115$ & $50-100$ \\
3. & $\mathrm{TSS}$ & $\mathrm{mg} / \mathrm{L}$ & $20-72$ & $45-100$ \\
4. & $\mathrm{pH}$ & - & $6,9-7,6$ & $6,0-9,0$ \\
\hline
\end{tabular}

*Sumber : Hasil Pengujian 


\section{Efisiensi Reduksi COD}

Gambar 2 menunjukkan konsentrasi COD air limbah influen dan efluen serta nilai prosentase reduksinya. Rentang nilai konsentrasi COD influen pada reaktor ini adalah $452-1012 \mathrm{mg} / \mathrm{L}$, sedangkan nilai konsentrasi COD efluen berada pada rentang $378-695 \mathrm{mg} / \mathrm{L}$. Sehingga dalam pengamatan percobaan selama 63 hari, nilai efisiensi reduksi COD yang dicapai adalah 16,29 - 38,50\%. Beban organik volumetrik reaktor MLMFC ini adalah $0,23-0,51 \mathrm{~kg} \mathrm{COD} / \mathrm{m}^{3}$.hari.

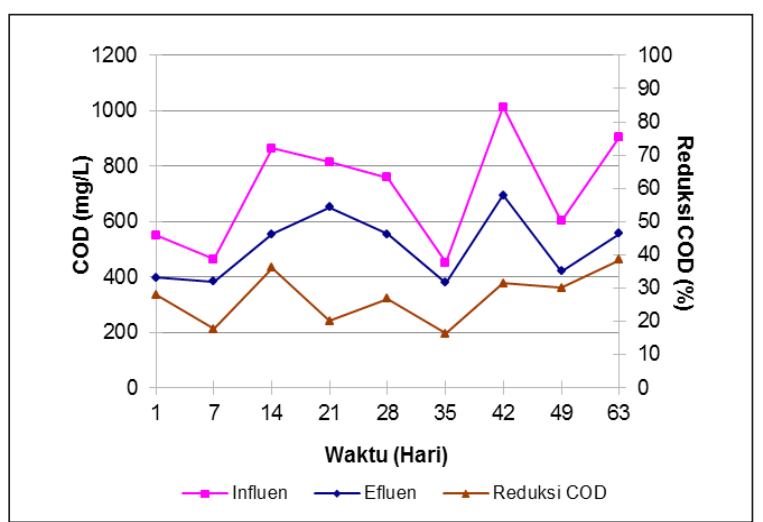

Gambar 2. Konsentrasi COD Influen dan Efluen serta Nilai Reduksinya

Reduksi nilai COD maksimum yang dapat dicapai pada percobaan ML-MFC ini adalah $38,50 \%$. Nilai efisiensi reduksi COD yang diperoleh reaktor ML-MFC tersebut memiliki nilai yang lebih tinggi daripada nilai efisiensi sebesar 29\% yang dihasilkan dari penelitian yang dilakukan Huang dkk., (2009) dengan substrat yang digunakan berupa air limbah industri kertas yang berbahan baku kertas bekas. Bahkan nilai reduksi COD percobaan ini jauh lebih tinggi lagi dibandingkan nilai reduksi COD sebesar 25,8\% yang diperoleh dari percobaan yang dilakukan oleh Ahn dan Logan (2010) dengan sumber organik dari air limbah domestik.

\section{Tegangan Listrik dan Efisiensi Reduksi COD}

Pada percobaan ML-MFC dengan air limbah industri pulp dan kertas sebagai substratnya,menunjukkan bahwa pembentukan energi listrik telah tercapai. Serangkaian nilai prosentase reduksi COD dan tegangan listrik yang timbul dapat dilihat pada Gambar 3 . Tegangan listrik yang terbentuk dalam waktu 63 hari percobaan adalah $8,0-118,8 \mathrm{mV}$, dengan nilai rata-rata $68,1 \mathrm{mV}$. Air limbah industri pulp dan kertas dialirkan ke dalam reaktor ML-MFC secara kontinu. Pada awal percobaan, terjadi peningkatan pada tegangan dan arus listrik hingga hari ke-7, kemudian turun secara perlahan mencapai titik minimal pada hari ke-49. Peningkatan nilai reduksi COD tidak diiringi dengan peningkatan tegangan dan arus listrik. Hal ini mungkin disebabkan oleh terjadinya proses metanogenesis dalam MFC. Metanogenesis dapat mengalihkan energi kimia dari pembangkit listrik (Kaur, dkk., 2014) sehingga listrik tidak terbentuk. Elektron yang timbul dari reaksi di ruang anoda tidak mengalir ke ruang katoda, tetapi digunakan untuk mereduksi senyawa organik dalam substrat air limbah menjadi metan.



Gambar 3. Nilai Reduksi COD dan Tegangan Listrik

\section{Daya Listrik pada Variasi Nilai Resistansi}

Satu rangkaian data daya listrik yang merupakan fungsi dari nilai resistansi tersebut dapat diperoleh dengan menggunakan variasi nilai resistansi $(100-5000 \Omega)$. Dari rangkaian data tersebut, kurva daya listrik terhadap nilai resistansi dapat dibuat, dapat dilihat pada Gambar 4. Elektroda yang berada pada ruang anoda memiliki luas permukaan sebesar 1,4778 $\mathrm{x} 10^{-2} \mathrm{~m}^{2}$. Seiring dengan penambahan nilai resistansi eksternal dari $100 \Omega$ sampai $5000 \Omega$, daya listrik yang dicapai akan meningkat sampai nilai resistansi tertentu, kemudian menurun kembali. Pada percobaan ini, nilai daya listrik maksimal sebesar $8,46 \mathrm{~mW} / \mathrm{m}^{2}$ dicapai pada nilai resistansi eksternal $500 \Omega$. Dengan demikian nilai resistansi eksternal juga merupakan salah satu faktor penting yang mengendalikan aliran elektron dalam sistem. 


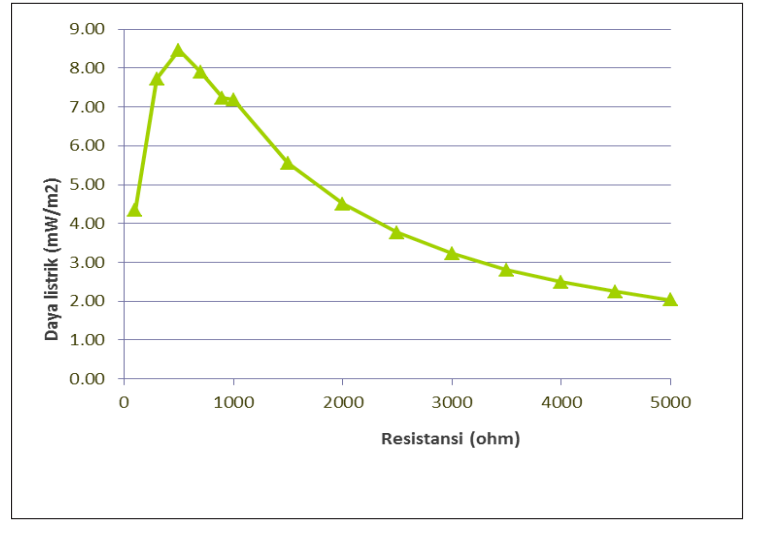

Gambar 4. Daya Listrik pada Variasi Nilai Resistansi

\section{Tegangan Listrik pada Variasi Nilai Resistansi}

Seperti yang dilakukan untuk daya listrik, dengan penggunaan variasi nilai resistansi dari100 $\Omega$ hingga $5000 \Omega$, rangkaian data tegangan listrik yang juga merupakan fungsi dari nilai resistansi pun dapat diperoleh. Dari rangkaian data tersebut, kurva tegangan listrik terhadap nilai resistansi dapat dibentuk, seperti terlihat pada Gambar 5.

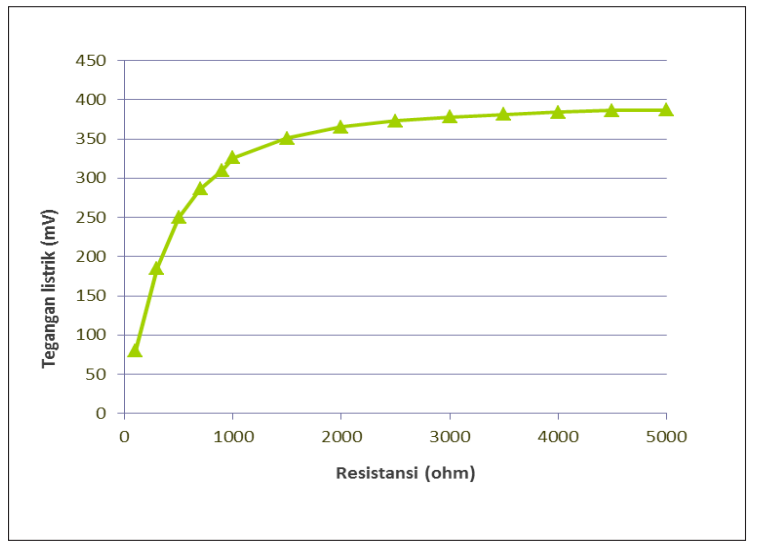

Gambar 5. Tegangan Listrik pada Variasi Nilai Resistansi

Variasi nilai tegangan listrik diperoleh dengan menggunakan variasi nilai resistansi pada saat pengukuran. Nilai tegangan listrik akan semakin tinggi seiring dengan meningkatnya nilai resistansi yang digunakan. Pada saat nilai resistansi yang digunakan $5000 \Omega$, nilai maksimum tegangan listrik terjadi sebesar 387 $\mathrm{mV}$. Pada saat tidak ada resistansi luar atau nilai resistansi sebesar nol maka tidak ada tegangan listrik yang terbentuk, karena dengan tidak adanya resistansi maka tidak ada perbedaan tegangan yang terjadi di titik anoda dan katoda. Untuk penambahan nilai resistansi dari $100 \Omega$ hingga $3000 \Omega$, peningkatan tegangan listrik yang diperoleh cukup berarti. Sedangkan pada nilai resistansi yang melebihi $3000 \Omega$, perubahan nilai tegangan listrik mendekati konstan.

\section{Arus Listrik pada Variasi Nilai Resistansi}

Untuk mendapatkan kurva arus listrik terhadap nilai resistansi, diperlukan satu rangkaian nilai arus listrik yang dapat diperoleh dengan menggunakan persamaan $\mathrm{I}=\mathrm{E} /$ Rext, (I adalah arus listrik $(\mathrm{mA}), \mathrm{E}$ adalah tegangan listrik $(\mathrm{mV})$, dan Rext adalah resistansi $(\Omega)$ ). Dengan demikian kurva arus listrik terhadap nilai resistansi dapat diperoleh, seperti terlihat pada Gambar 6.

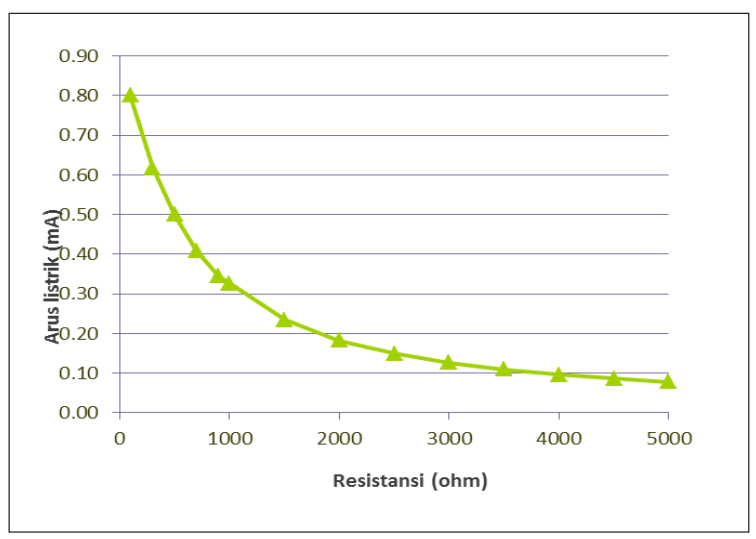

\section{Gambar 6. Arus Listrik Pada Variasi Nilai Resistansi}

Dengan meningkatnya nilai resistansi yang dipergunakan pada sistem maka terjadi penurunan arus listrik pada seluruh rangkaian. Penurunan arus listrik ini bergerak menuju titik minimum sebesar $0,07 \mathrm{~mA}$ yang terukur pada saat nilai resistansi sebesar $5000 \Omega$. Pada saat nilai resistansi yang digunakan sebesar $100 \Omega$, nilai maksimum arus terjadi sebesar $0,80 \mathrm{~mA}$. Seiring dengan penambahan nilai resistansi dari $100 \Omega$ hingga $3000 \Omega$, penurunan arus listrik yang melewati rangkaian system cukup berarti. Sedangkan untuk nilai resistansi melebihi $3000 \Omega$, perubahan nilai arus listrik mendekati konstan. Oleh karena itu, dengan penambahan nilai resistansi eksternal, terjadi penurunan nilai arus listrik pada seluruh variasi nilai resistansi eksternal dan arus listrik akan berada pada nilai minimal pada nilai resistansi eksternal $5000 \Omega$. 


\section{Daya Listrik, Tegangan Listrik dan Arus Listrik}

Kurva polarisasi menunjukkan kinerja MFC untuk mempertahankan nilai tegangan listrik seiring dengan peningkatan nilai arus listriknya. Kurva densitas daya memperlihatkan daya listrik yang dapat diberikan oleh sistem MFC yang juga merupakan fungsi dari nilai arus listrik. Dari kurva densitas daya, nilai daya listrik maksimal yang dicapai oleh sistem dapat diketahui.

Pencarian nilai hambatan ekternal $\mathrm{R}$ yang optimal telah dapat diketahui dengan cara pengukuran nilai tegangan listrik dan arus listrik dengan variasi nilai beban resistor $100 \Omega$ $-5000 \Omega$. Hal ini dilakukan untuk mengetahui daya listrik maksimum yang dapat ditimbulkan oleh sistem terhadap variasi resistansi yang digunakan. Daya listrik yang terlihat pada Gambar 7 merupakan fungsi dari arus listrik dengan variasi beban listrik dalam sistem MLMFC antara $100 \Omega-5000 \Omega$. Penggunaan nilai resistansi listrik ini konsisten dengan percobaanpercobaan lain seperti yang dilakukan oleh Liu dkk (2004a).

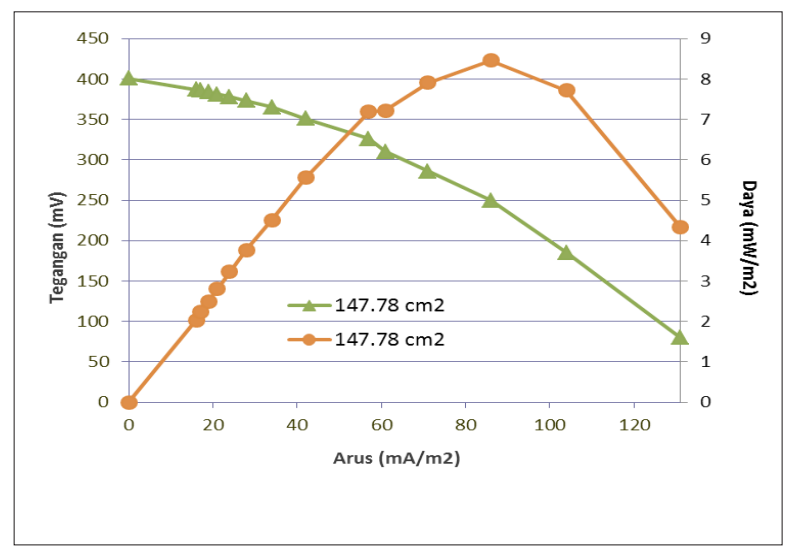

Gambar 7. Kurva Polarisasi dan Kurva Densitas Daya Listrik

Pada percobaan ini, daya listrik maksimum yang diperoleh pada luas permukaan anoda sebesar $1,4778 \times 10^{-2} \mathrm{~m}^{2}$ adalah $8,46 \mathrm{~mW} / \mathrm{m}^{2}$, pada saat nilai arus listrik $101,50 \mathrm{~mA} / \mathrm{m}^{2}$ dan pada beban resistansi $500 \Omega$. Nilai daya listrik tersebut masih berada di bawah nilai daya listrik yang dilakukan oleh Liu dkk (2004b) dengan nilai maksimum $26 \mathrm{~mW} / \mathrm{m}^{2}$, yang menggunakan air limbah domestik sebagai substrat. Daya listrik yang dihasilkan untuk suatu substrat memiliki nilai yang bervariasi tergantung pada desain MFC, namun pada umumnya substrat air limbah menghasilkan listrik yang lebih rendah dibandingkan dengan yang dihasilkan dari substrat organik murni (Feng dkk, 2008). Dari hasil percobaan ini dapat dikatakan bahwa produksi listrik dalam reaktor ML-MFC memiliki harapan yang optimis dan dapat menjadi pilihan yang menarik untuk memproduksi listrik, pada saat yang bersamaan dengan berlangsungnya pengolahan air limbah (Ghangrekar dan Shinde, 2006a).

\section{KESIMPULAN}

Membrane-less Microbial Fuel Cell (MLMFC) dengan menggunakan batang karbon sebagai elektroda dan air limbah industri pulp dan kertas sebagai substrat organik menunjukkan adanya potensi dapat memproduksi energi listrik. Dari hasil pemanfaatan operasi IPAL air limbah industri pulp dan kertas dengan reduksi maksimum nilai COD sebesar 38,50\%, menghasilkan tegangan listrik maksimum yang dapat dicapai adalah $118,8 \mathrm{mV}$. Daya listrik maksimum yang diperoleh pada luas permukaan anoda sebesar $1,4778 \times 10^{-2} \mathrm{~m}^{2}$ adalah $8,46 \mathrm{~mW} /$ $\mathrm{m}^{2}$ dengan nilai arus listrik $101,50 \mathrm{~mA} / \mathrm{m}^{2}$ dan beban resistansi $500 \Omega$.

\section{UCAPAN TERIMA KASIH}

Terima kasih disampaikan kepada Balai Besar Pulp dan Kertas atas dana penelitian yang diberikan dan kepada seluruh anggota tim yang membantu pelaksanaan penelitian ini.

\section{DAFTAR PUSTAKA}

Ahn, Y., Logan, B.E., 2010. Effectiveness of Domestic Wastewater Treatment Using Microbial Fuel Cells at Ambient and Mesophilic Temperatures. Bioresource Technology 101, 469-475.

Feng, Y., Wang, X., Logan, B.E., Lee, H., 2008. Brewery Wastewater Treatment Using Air-Cathode Microbial Fuel Cells. Appl. Microbiol. Biotechnol. 78, 873-880.

Ghangrekar, M.M., Shinde, V.B., 2006a. Performance of Membrane-Less Microbial Fuel Cell Treating Wastewater and Effect of Electrode Distance and Area on Electricity Production. Bioresource Technology. 
Ghangrekar, M.M., Shinde, V.B., $2006 b$. Wastewater Treatment in Microbial Fuel Cell and Electricity Generation: A Sustainable Approach. Paper presented in the 12th international sustainable development research conference. April 6-8, Hong Kong.

Huang, L., Cheng, S., Rezaei, F., Logan, B.E., 2009. Reducing Organic Loads in Wastewater Effluents from Paper Recycling Plants Using Microbial Fuel Cells. Environmental Technology 30 (5), 499-504.

Jang, J.K., Pham, T.H., Chang, I.S., Kang, K.H., Moon, H., Cho, K.S., Kim, B.H., 2004. Construction and Operation of A Novel Mediator and Membrane-Less Microbial Fuel Cell. Process Biochem. 39, 1007-1012.

Kaur, A., Boghani, H.C., Michie, I., Dinsdale, R. M., Guwy,A.J.,Premier, G.C. 2014. Inhibition of Methane Production in Microbial Fuel Cells: Operating Strategies Which Select Electrogens Over Methanogens. Bioresource Technology Vol. 173, 75-81.

Kim, B.H., Park, H.S., Kim, H.J., Kim, G.T., Chang, I.S., Lee, J., Phung, N.T., 2004. Enrichment of Microbial Community Generating Electricity Using A Fuel Cell Type Electrochemical Cell. Appl. Microbiol. Biotechnol. 63, 672-681.

Liu, H., Logan, B.E., 2004a. Electricity Generation Using an Air-Cathode Single Chamber Microbial Fuel Cell in the Presence and Absence of a Proton Exchange Membrane. Environmental Science Technology 38, 4040-4046.
Liu, H., Ramnarayanan, R., Logan, B. E., $2004 b$. Production of Electricity during Wastewater Treatment Using a Single Chamber Microbial Fuel Cell. Environ. Sci. Technol. 38, 22812285.

Logan, B.E., 2009. Exoelectrogenic Bacteria that Power Microbial Fuel Cells. Nature Reviews 7, 375-381.

Logan, B.E., 2008. Microbial Fuel Cells. John Wiley \& Sons: Hoboken, NJ.

Logan, B.E. 2004. Feature Article: Extracting Hydrogen and Electricity from Renewable Resources. Environ. Sci. Technol., 38, 160A-167A.

Logan, B.E., Regan, J. M., 2006. Microbial Fuel Cells-Challenges and Applications. Environ. Sci. Technol. 40, 5172-5180.

Pant, D., Bogaert, G. V., Diels, L., Vanbroekhoven, K., 2009. A Review of the Substrates Used in Microbial Fuel Cells (MFCs) For Sustainable Energy Production. Bioresource Technology, doi:10.1016/j.biortech.2009.10.017

You, S., Zhao,Q., Zhang, J., Jiang, J., Wan, C., Du, M., Zhao, S., 2007. A Graphite-Granule Membrane-Less Tubular Air-Cathode Microbial Fuel Cell for Power Generation Under Continuously Operational Conditions. Journal of Power Sources 173, 172-177. 
Lurnal Selulosa, Vol. 5, No. 1, Juni 2015: 39 - 46 